\title{
EDUKASI MANAJEMEN DEMAM DALAM PENGENDALIAN KEJANG DEMAM PADA ANAK DI MASA PANDEMI COVID-19
}

\author{
Nor Isna Tauhidah ${ }^{*}$, Yosra Sigit Pramono² \\ 1-2Universitas Muhammadiah Banjarmasin
}

Email Korespondensi: norisnatauhidah112@umbjm.ac.id

Disubmit: 23 Juli $2021 \quad$ Diterima: 01 Agustus $2021 \quad$ Diterbitkan: 04 Februari 2022 DOI: https://doi.org/10.33024/jkpm.v5i2.4709

\begin{abstract}
ABSTRAK
Masalah kesehatan yang paling sering terjadi pada anak- anak yaitu demam, demam merupakan gejala dari suatu penyakit yang jika tidak teratasi dengan baik dapat mengakibatkan komplikasi seperti kejang demam pada anak. Penting bagi orangtua untuk mampu melakukan penanganan demam dengan baik dan benar. Kegiatan pengabdian pada masyarakat ini dilakukan untuk meningkatkan pengetahuan dan pemahaman tentang manajemen demam guna mencegah atau mengendalikan terjadinya kejang demam pada anak. Metode yang dilakukan adalah dengan cara ceramah, tanya jawab serta demostrasi tentang manajemen demam yang dapat dilakukan oleh orangtua saat anaknya mengalami demam. Hasil dari kegiatan didapatkan peningkatan pengetahuan orangtua sebesar $10 \%$ tentang manajemen demam.
\end{abstract}

Kata Kunci: Edukasi, Kejang Demam, Manajemen Demam

\begin{abstract}
Healthy problems that most often occur in children are fever. fever is a symptom of a disease which if not handled properly can lead to complications such as febrile seizures in children. It is important for parents to be able to handle fever properly and correctly. This community service activity is carried out to increase knowledge and understanding of fever management in order to prevent or control the occurrence of febrile seizures in children. The method used is by means of lectures, questions, answers, demonstrations about fever management that can be done by parents when their child has a fever. The results of the activity showed an increase in parents' knowledge is $10 \%$ about fever management.
\end{abstract}

Keywords: Education, Fever Management, Fever Seizures 


\section{PENDAHULUAN}

Penyakit yang sering terjadi pada anak sering di awali dengan berbagai keluhan di antaranya demam, batuk, mencret, kejang, muntah, edema, sesak nafas, sianosis, ikterus dan perdarahan. Keluhan demam merupakan keluhan yang sering terjadi berbagai penyakit baik infeksi maupun non infeksi. Menurut Ikatan Dokter Anak Indonesia (IDAI, 2015) sekitar 30\% dari seluruh total kunjungan tersering ke dokter anak dan dokter umum adalah demam anak. Demam yang terjadi pada anak menjadi perhatian khusus bagi ibu karena dampak merugikan yang muncul jika demam tidak diatasi. Ibu dapat mengalami kecemasan sehingga pengobatan mandiri menjadi upaya terbanyak yang dilakukan. Informasi yang tidak akuntabel dapat mengarahkan ibu kepada pengelolaan demam yang tidak tepat. Pemberian edukasi tentang pengelolaan demam yang komprehensif sangat diperlukan di tatanan unit rawat jalan (Rachmawati and Kartika, 2020).

Demam adalah suatu keadaan terjadinya peningkatan suhu tubuh. Demam merupakan kondisi suhu tubuh diatas $37.5^{\circ} \mathrm{C}$, sedangkan keadaan hiperpireksia atau hipertermi (demam tinggi) adalah kenaikan suhu tubuh sampai $41^{\circ} \mathrm{C}$ atau lebih. Peningkatan suhu tubuh ini sebagai respon terhadap infeksi atau peradangan, dimana demam sering menjadi alasan mengapa orang tua membawa anaknya ke pelayanan kesehatan. Kejang merupakan suatu perubahan fungsi pada otak secara mendadak dan sangat singkat atau sementara yang dapat disebabkan oleh aktifitas yang abnormal serta adanya pelepasan listrik serebal yang berlebihan. Kejang Demam adalah bangkitan kejang yang terjadi pada kenaikan suhu tubuh (suhu rektal di atas $38^{\circ} \mathrm{C}$ ) yang disebabkan oleh proses ekstrakranium (Wong, 2014). Kejang demam merupakan tipe kejang yang sering ditemukan pada masa kanak-kanan. Angka kejadian kejang demam terjadi 2-5\% pada anak Hasil penelitian menunjukkan bahwa Kejang demam paling sering terjadi pada anak laki-laki dan diagnosis jenis kejang demam kompleks (Kakalang, Masloman and Manoppo, 2016).

Orang tua, khususnya ibu sering mempunyai informasi yang tidak lengkap mengenai lokasi, durasi dan metode pengukuran suhu tubuh. Pengetahuan ibu yang kurang tentang demam anak dapat menyebabkan pengelolaan yang tidak tepat. Pengalaman mengatasi demam sebelumnya juga dapat mempengaruhi ketepatan pengelolaan demam anak. Cahyaningrum (2018). Menurut penelitian yang dilakukan di Ghana terhadap 100 responden, ibu memiliki beberapa pengelolaan dalam menangani demam seperti; memberikan pengobatan sendiri (43\%), berkonsultasi dengan ahli herbal (20\%), melakukan kompres spons (28\%) dan mengunjungi RS terdekat (62\%) (Rachmawati and Kartika, 2020).

Penanangan demam pada anak sangat tergantung pada peran orang tua, terutama ibu. Ibu yang tahu tentang demam dan memiliki sikap yang baik dalam memberikan perawatan dapat menentukan penangan demam yang terbaik pada anaknya (Cahyaningrum, 2016).

Menurunkan atau mengendalikan dan mengontrol demam pada anak dapat dilakukan dengan berbagai cara, diantaranya dapat dilakukan dengan pemberian antipiretik (farmakologik).Selain penggunaan obat antipiretik, penurunan suhu tubuh dapat dilakukan secara fisik (non farmakologik) yaitu dengan penggunaan energi panas melalui metoda konduksi dan evaporasi. 
Metode konduksi yaitu perpindahan panas dari suatu objek lain dengan kontak langsung. Ketika kulit hangat menyentuh yang hangat maka akan terjadi perpindahan panas melalui evaporasi, sehingga perpindahan energi panas berubah menjadi gas(Potter \& Perry, 2005).

Penatalaksanaan demam terdiri dari farmakologi dan nonfarmakologi, diantaranya pemberian obat antipiretik, memberikan minum air putih atau pun ASI untuk bayi, pengaturan suhu ruangan, dan pemberian kompres hangat (Ramadhanti et al., 2020). Pemberian kompres hangat dan tepid sponge efektif dalam menurunkan suhu tubuh, namun penelitian menjelaskan bahwa tepid sponge jauh lebih efektif di karenaka menggunakan metode seka sehingga mempercepat vasodilatasi pembulh darah perfifer sehingga mempercepat proses evaporasi (Dewi, 2016). Penanganan demam yang di alami oleh bayi maupun anak-anak juga sangat di pengaruhi oleh pengetahuan setiap orangtua. Sehingga orangtua sangat perlu mengetahui informasi terkait bagaiamana penganganan demam, karena masih banyak orangtua yang belum memahami dengan baik atau memiliki pengetahuan yang kurang (Wulandini, Saputra and Frilianova, 2019) pendidikan kesehatan merupakan salah satu metode efektif untuk meningkatkan pengetahuan dan sikap orangtua dalam penanganganan kejang demam khususnya, dengan meningkatnya sikap orangtua menjadi lebih baik. diharapkan mampu mengengendalikan dan mengatasi kejang demam (Puspita, Maghfirah and Sari, 2019).

Penanganan demam pada anak sangat tergantung pada peran orangtua, terutama ibu. Dari berbagai penelitian yang dilakukan di Indonesia, diketahui bahwa tingkat pengetahuan ibu tentang penanganan demam pada anak sangat bervariasi. Perbedaan tingkat pengetahuan ini dapat mengakibatkan perbedaan pengelolaan demam pada anak. Begitu pula terkait kemudahan untuk membeli antipiretik secara bebas dan peran ibu yang penting dalam kesehatan keluarga, penanganan demam pada anak oleh ibu menjadi hal yang penting. Pengetahuan yang kurang dapat mengakibatkan penanganan yang tidak tepat sehingga membuat kesehatan anak menjadi lebih berisiko (Sudibyo et al., 2020).

Intervensi pemberian manajemen demam sangat memberikan manfaat untuk peningkatan kemampuan orangtua secara mandiri tentang pengetahuan dan keterampilan dalam melakukan penanganan demam secara cepat dan bijak. Penanganan demam yang dapat dilakukan oleh orangtua secara mandiri yaitu dengan mengidentifikasi dema, bagaimana dan seperti ap acara yang dapat di lakukan orangtua saan anaknya mengalami demam (Susanti, Sutini and Haryanto, 2021) Adapun tujuan dalam kegiatan pengabdian ini untuk meningkatkan pemahaman dan pengetahuan ibu tentang manajemen demam sehingga dapat mencegah atau mengendalikan terjadinya kejang demam.

\section{MASALAH}

Permasalah utama dari penatalaksanaan demam serta pencegahan kejang demam yang sering terjadi pada anak adalah belum optimalnya penanggangan demam pada anak, sehingga diperlukan edukasi terkait bagaimana manajemen demam pada anak guna mencegah atau mengendalikan timbulnya kejang deman yang terjadi pada anak di rumah terutama di masa pandemi covid-19. 
Berdasarkan survey kejang demam masih sering terjadi banyak laporan dan rekam medis terkait kejadian demam pada anak di wilayah kerja puskesmas Alalak Selatan, sehingga penting dilaksanakan edukasi terkait pengananan demam.

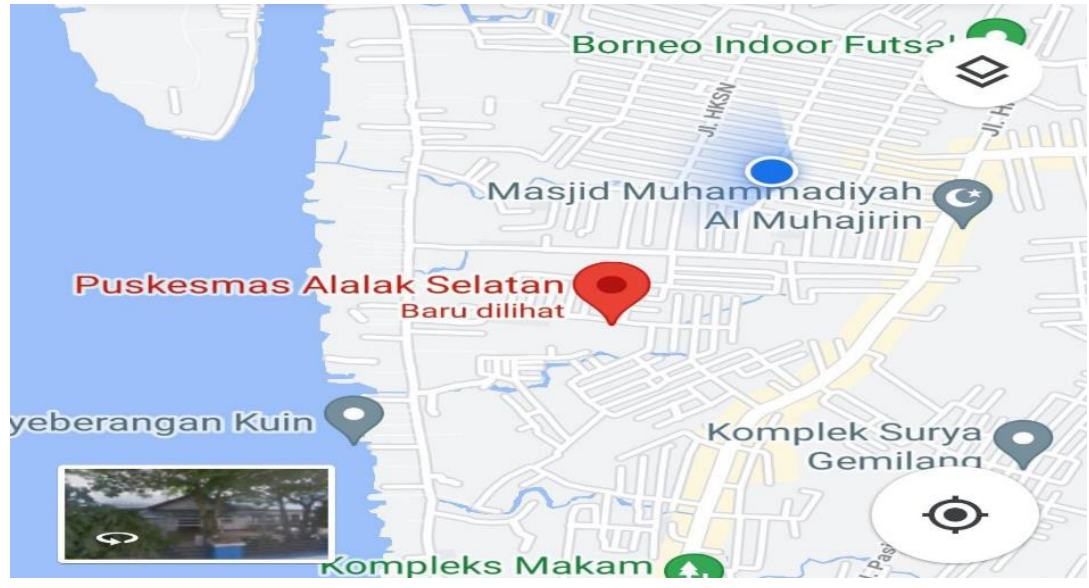

Gambar 1. Peta Lokasi kegiatan Pengabdian masyarakat

\section{METODE}

a. Tahap Persiapan

Pada tahap persiapa tim pengabdian melakukan survey awal terkait kasus demam dan kejang demam dengan melakukan pendekatan kepada pihak Puskesmas dengan tujuan untuk memperoleh data dan merencanakan kegiatan. Kemudian tim pengabdian menyusun hal-hal yang dibutuhkan antara lain sarana dan bahan yang digunakan dalam kegiatan, dan juga mengurus perizinan.

\section{b. Tahap Pelaksanaan}

Tahap pelaksanaan diawali dengan melakukan Pre test untuk mengukur pemahaman ibu tentang manajemen demam, dilanjutkan dengan Kegiatan pengabdian kepada masyarakat ini berupa edukasi manajemen demam oleh tim pengabdian dalam 1 kali pertemuan dengan waktu 2 jam dikemas dalam metode ceramah dan tanya jawab, serta demonstasi mengenai manajemen demam dengan tema meliputi gambaran demam dan kejang demam, penyebab demam, hal-hal yang harus diperhatikan saat demam, manajemen demam dan demontrasi tentang kompres hangat, water tepid sponge.

\section{c. Evaluasi}

i. Struktur

Peserta hadir sebanyak 10 orang yang merupakan kader Kesehatan di wilayah kerja Puskesmas Alalak Selatan. Tempat kegiatan sudah sesuai dengan rencana yang dibuat dan perlengkapan yang dilakukan untuk memberikan edukasi sudah tersedia dan sudah digunakan sebagaiaman mestinya. Bahasa yag digunakan selama komunikasi mudah dapat dipahami oleh peserta. 


\section{ii. Proses}

Pelaksanaan kegiatan dimulai pukul 09.30 s.d 11.00 WITA sesuai dengan jadwal yang telah direncanakan. Kegiatan berjalan lancar, peserta mengikuti kegiatan sampai selesai dan sesuai rencana. Peserta juga berperan aktif dengan mengajukan beberapa pertanyaan selama diskusi berlangsung.

\section{HASIL DAN PEMBAHASAN}

Pelaksanaankegiatan dilakukan di aula pertemuan puskesmas Alalak selatan dengan 10 orang ibu-ibu. Media yang digunakan dalam kegiatan ini berupa materi edukasi manajemen demam, termometer, alat kompres. Tim pengabdian melakukan kegiatan di pandu oleh moderator dengan diawali acara pembukaan dan sambutan dari kepala puskesmas, kemudian kegiatan dilanjutkan dengan melakukan Pre test selama 15 menit untuk mengukur pemahaman ibu tentang manajemen demam sebelum mereka mendapatkan edukasi. Setelah itu kegiatan pengabdian kepada masyarakat ini masuk ke acara inti berupa edukasi manajemen demam, tim memberikan informasi dan penjelasan terkait topik dengan metode ceramah dan tanya jawab serta memutarkan video tentang manajemen demam seperti cara melakukan kompres hangat dan tepid water sponge. Adapun materi yang dijelaskan untuk manajemen demam meliputi gambaran demam dan kejang demam, penyebab demam, hal-hal yang harus diperhatikan saat demam, manajemen demam dan demontrasi tentang kompres hangat, water tepid sponge. Tahap terakhir yakni tahap evaluasi dengan melakukan postest terkait pemahaman ibu setelah dilakukan intervensi untuk mengetahui pemahaman akhir atau mengevaluasi bagaimana perubahan yang terjadi terkait pemahaman responden.

Berdasarkan hasil pre test dan post test didapatkan peningkatan pengetahuan ibu dan kader kesehatan sebelum dan sesudah kegiatan. Nilai rata-rata hasil evaluasi sebelum kegiatan adalah 68, sedangkan setelah kegiatan skor rata-rata meningkat menjadi 78 . Didapatkan peningkatan rata-rata $10 \%$ dari sebelumnya. Selama kegiatan ini tidak di dapatkan hambatan, seluruh peserta antusias dan aktif selama kegiatan serta mengatakan senang dan merasakan manfaat atas kegiatan yang dilaksanakan. Peserta juga mengharapkan kegiatan seperti ini dapat berlangsung dilain waktu. Adanya respon positif dari kegiatan ini memberikan motvasi dan semangat bagi kami sehingga berusaha untuk melaksanakan kegiatan-kegiatan lain dengan lebih baik lagi.

Berikut gambar-gambar kegiatan pengabdian masyarakat: 


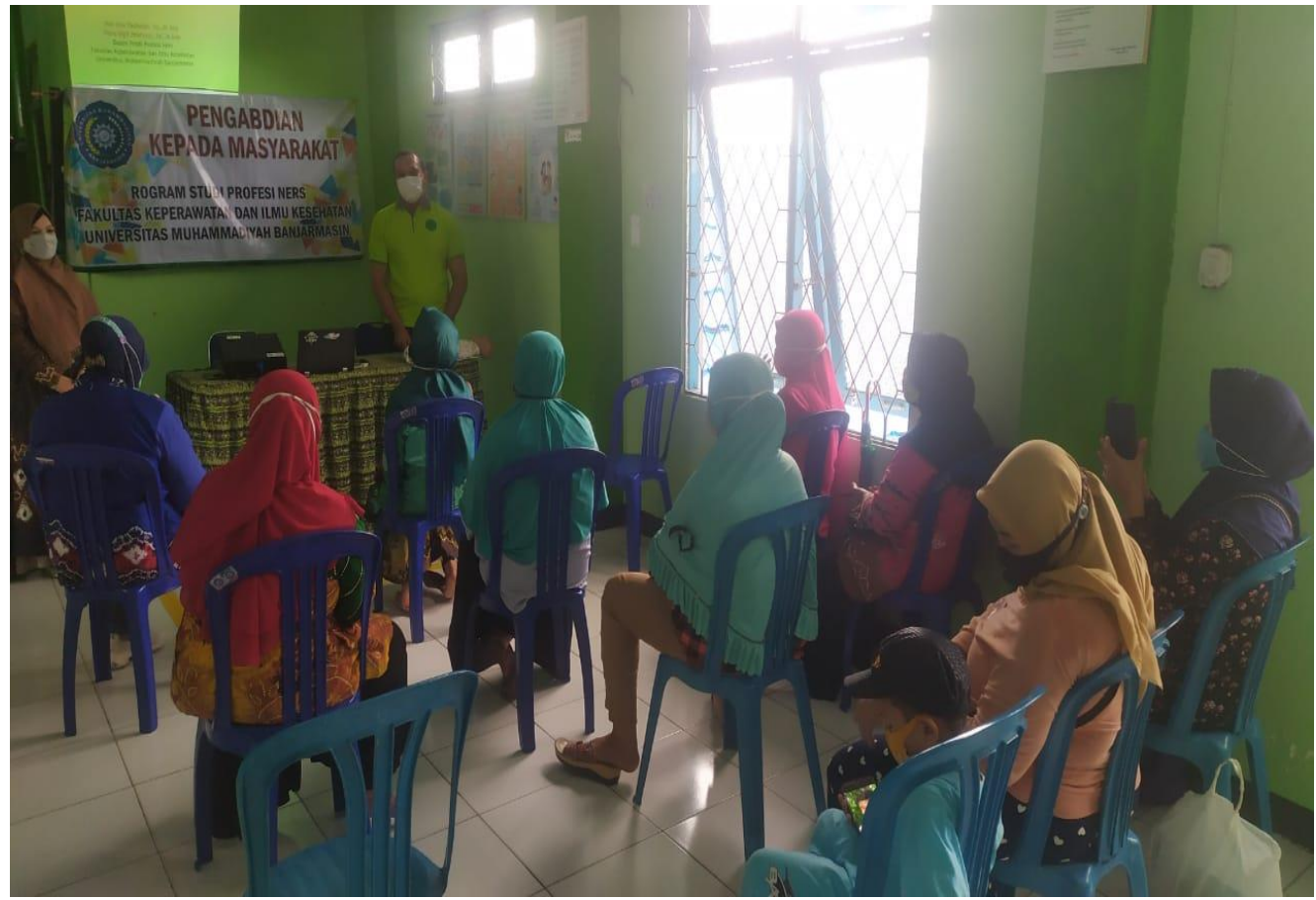

Gambar 2. Kegiatan PKM

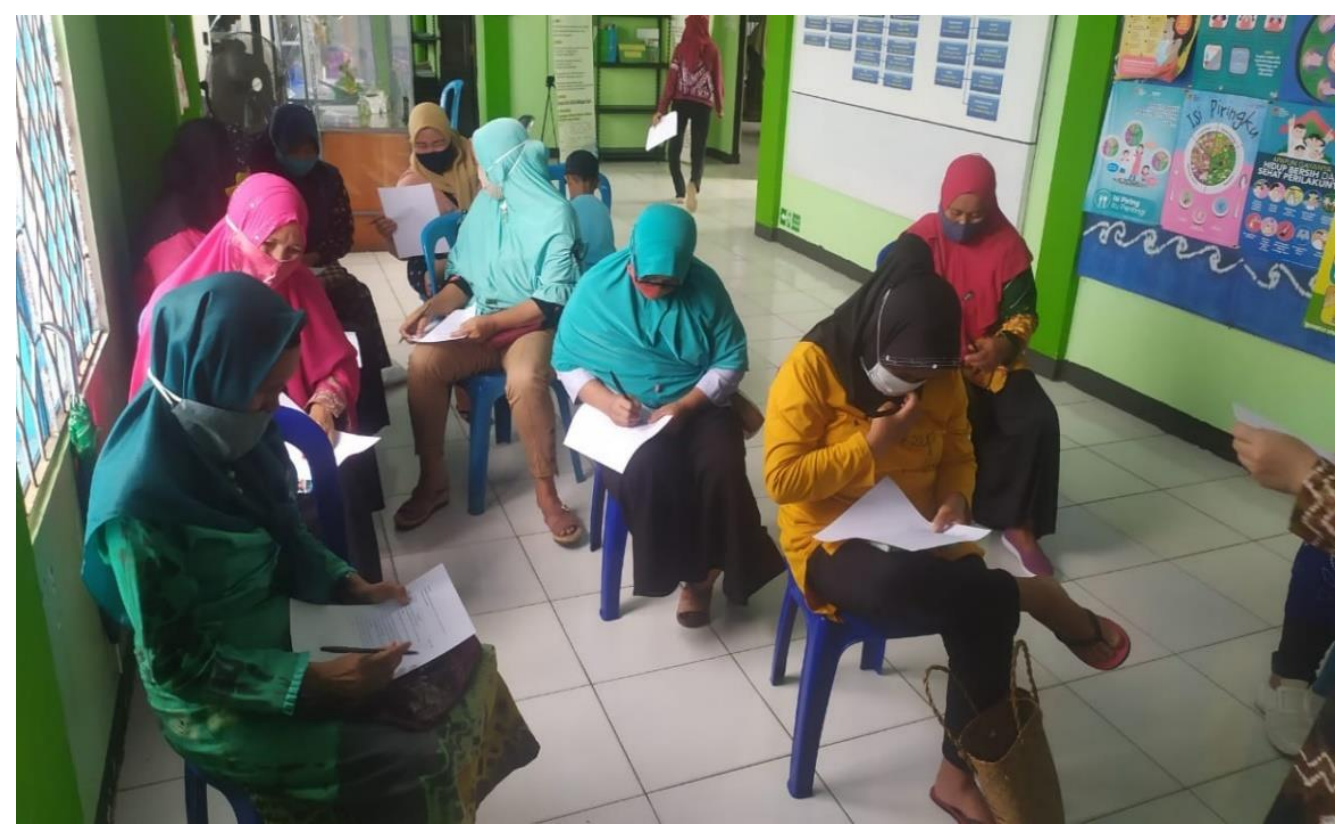

Gambar 3. Kegiatan PKM 


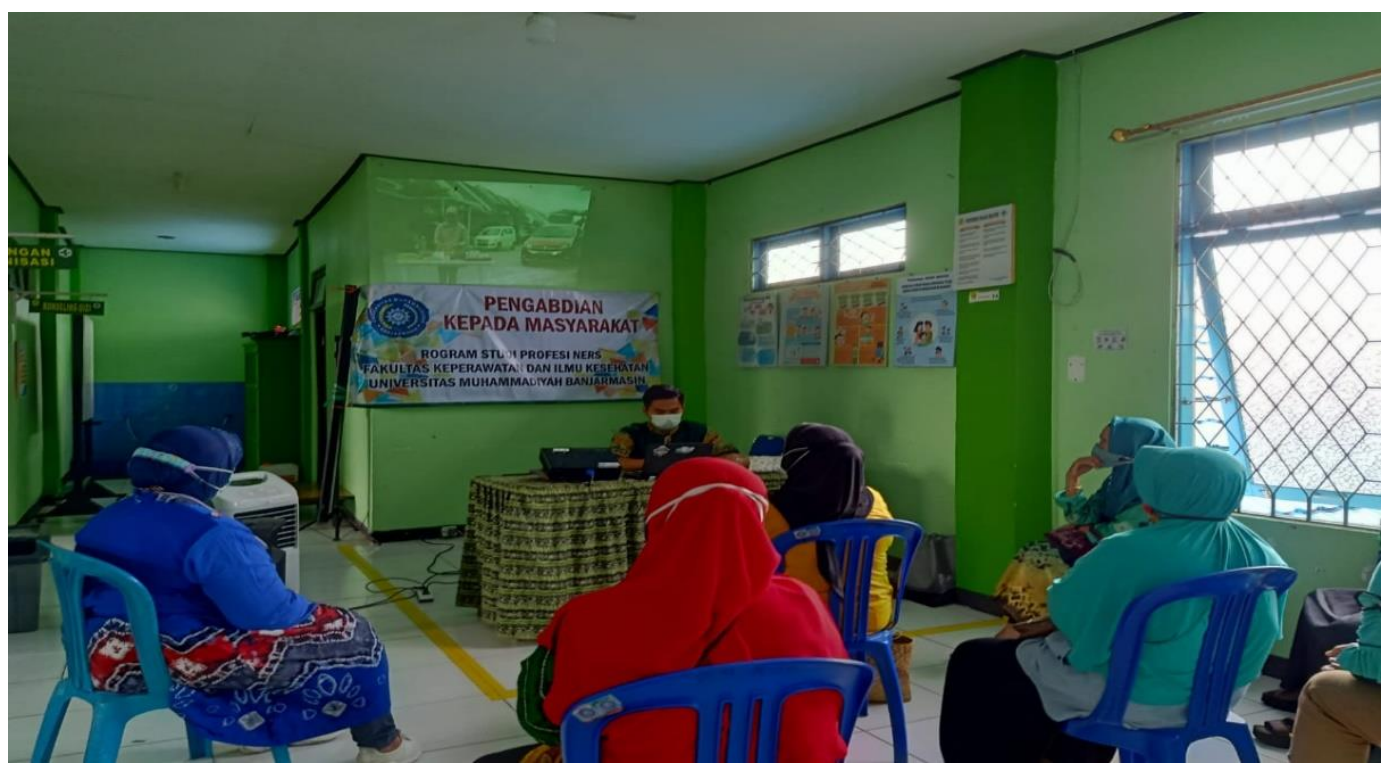

Gambar 4. Kegiatan PKM

\section{KESIMPULAN}

Program pelatihan dapat diselenggarakan dengan baik dan berjalan dengan lancar sesuai dengan rencana kegiatan yang telah disusun. Kegiatan ini mendapat sambutan sangat baik terbukti dengan keaktifan peserta mengikuti latihan dan dengan tidak meninggalkan tempat sebelum waktu pelatihan berakhir. Hasil pengabdian ini di dapatkan ada peningkatan pengetahuan tentang manajemen deman dan pencegahan kejang demam.

\section{DAFTAR PUSTAKA}

Cahyaningrum, E. D. (2016) 'Penatalaksanaan anak demam oleh orang tua di puskesmas kembaran I banyumas', Viva Medika, 09(17), pp. 44-53. Available

at: https://ejournal.uhb.ac.id/index.php/VM/article/view/127.

Dewi, A. K. (2016) 'Perbeedaan Penurunan Suhu Tubuh Antara Pemberian Kompres Hangat Dengan Tepid Sponge Bath Pada Anak Demam', Jurnal Keperawatan Muhammadiyah, 1(1), pp. 63-71. Available at: http://journal.umsurabaya.ac.id/index.php/JKM/article/view/366/272.

Kakalang, J. P., Masloman, N. and Manoppo, J. I. C. (2016) 'Profil kejang demam di Bagian Ilmu Kesehatan Anak RSUP Prof. Dr. R.D. Kandou Manado', Jurnal e-Clinic (eCl) Volume 4, Nomor 2, Juli-Desember 2016, 4(2), pp. 1-6.

Potter \& Perry (2005) 'Buku Ajar Fundamental Keperawatan: Konsep, Proses \& Praktek. Edisi 4. Vol 1.', in. Jakarta: EGC.

Puspita, R. I., Maghfirah, S. and Sari, R. M. (2019) 'PENYULUHAN KESEHATAN 
MENGGUNAKAN MEDIA VIDEO TERHADAP PENGETAHUAN IBU DALAM PENCEGAHAN KEJANG DEMAM BALITA di Dukuh Ngembel Desa Baosan Lor Kecamatan Ngrayun Kabupaten Ponorogo', Health Sciences Journal, 3(1), p. 23. doi: 10.24269/hsj.v3i1.220.

Rachmawati, A. and Kartika, L. (2020) 'Pengetahuan Ibu dan Pengelolaan Demam Anak di Satu Rumah Sakit Swasta di Indonesia Barat', Jurnal Keperawatan Raflesia, 2(1), pp. 11-20. doi: 10.33088/jkr.v2i1.506.

Ramadhanti, A. et al. (2020) '7 1,2,3', 3, pp. 382-387.

Sudibyo, D. G. et al. (2020) 'Pengetahuan Ibu Dan Cara Penanganan Demam Pada Anak', Jurnal Farmasi Komunitas, 7(2), p. 69. doi: 10.20473/jfk.v7i2.21808.

Susanti, D., Sutini, T. and Haryanto, R. (2021) 'Pengaruh Aplikasi Manajemen Demam Terhadap Kemandirian Orang Tua Dalam Penanganan Demam pada Balita di Wilayah Kerja Puskesmas Kecamatan Kebayoran Baru', Jurnal Ilmiah Kesehatan, 13(1), pp. 38-46. doi: 10.37012/jik.v13i1.411.

Wulandini, P., Saputra, R. and Frilianova, D. (2019) 'Tingkat Pengetahuan Ibu Tentang Kejang Demam Pada Anak Usia 6 Bulan Sampai 5 Tahun Di Puskesmas Kampar Timur 2018', Jurnal Keperawatan Abdurrab, 2(2), pp. 57-67. doi: 10.36341/jka.v2i2.625. 